UNDERGRADUATE RESEARCH IN NATURAL AND CLINICAL SCIENCE AND TECHNOLOGY (URNCST) JOURNAL Read more URNCST Journal articles and submit your own today at: https://www.urncst.com

\title{
Bioremediation: How to Decrease Greenhouse Gas Emissions Through Cattle
}

\author{
Atiya Sekyi-Otu, HBSc Student [1]*, Alexa Smith, HBSc Student [2] \\ [1] Department of Human Health and Nutritional Sciences, University of Guelph, Guelph, \\ Ontario, Canada N1G 2W1 \\ [2] Department of Biomedical Science, University of Guelph, Guelph, Ontario, \\ Canada N1G 2W1
}

*Corresponding Author: asekyiot@uoguelph.ca

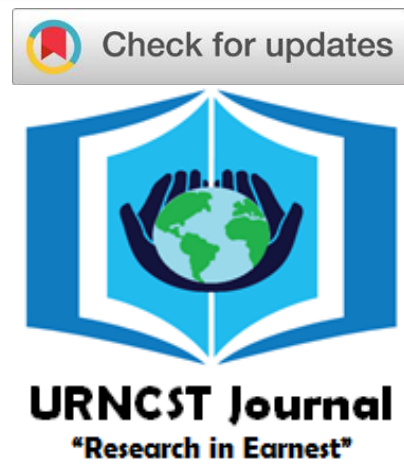

\begin{abstract}
Introduction: The concentration of greenhouse gases within the atmosphere is currently on the rise. With the increase in human population comes a growing need for greater food security in order to support our population. The agricultural industry has a carbon footprint comparable to that of other extensive producers such as oil production facilities, waste sectors and industrial processors. This study aims to establish an experimental design to modify the current microbiome in cattle, as cattle farming practices account for a majority of agricultural methane production in North America.

Methods: Young Canadian Holstein cattle with developing ruminal microbiomes will be placed into control and treatment groups and studied over the duration of 4 weeks. Ruminococcus hydrogenotrophicus will be inserted into the rumen of the experimental groups of cattle.

Results: Results will generate findings on the basis of reducing methanogenic activity among the rumen of cattle, and therefore the results may propose a feasible answer towards the decreasing of the agricultural carbon footprint among the cattle industry.

Discussion: The ability to decrease or eliminate the methane produced from agriculture would be a significant finding in current global studies. Through/by combining knowledge from environmental biology, agricultural science, microbiology and animal biology, solutions can be found for reducing the agricultural carbon footprint.

Conclusion: The use of bioremediation methods to decrease methane production is a new area of research. By cultivating a microorganism that can compete with the methanogenic bacteria within the rumen of cows, less methane yield is plausible. Ultimately, leading to a proposed answer to curb climate change values to a decreasing end.
\end{abstract}

Keywords: acetogen; bioremediation; cattle; climate change; microbiome; ruminal methane

\section{Introduction}

Climate change threatens the existence of all life on this planet. Methane $\left(\mathrm{CH}_{4}\right)$ is one of the most potent greenhouse gases in the atmosphere; incrementally stronger than carbon dioxide $\left(\mathrm{CO}_{2}\right)$ [1]. The majority of $\mathrm{CH}_{4}$ emissions can be traced back to the agricultural industry. Around $16 \%$ of the global $\mathrm{CH}_{4}$ emissions come from ruminants. Cows are ruminants with a diet containing large amounts of fodder and other plant material that are high in fibre. Ruminants make use of indigestible fibre dense carbohydrates for energy, from rumination [2]. This process creates methane gas through digestive methanogenic microorganisms that are part of the gut microbiome. Species of methanogenic archaea are capable of utilizing hydrogen $\left(\mathrm{H}_{2}\right)$ and $\mathrm{CO}_{2}$ to form $\mathrm{CH}_{4}$ [3]. $\mathrm{H}_{2}$ is transferred from species of bacteria, protozoa and fungi to methanogenic archaea, which use $\mathrm{H}_{2}$ to reduce $\mathrm{CO}_{2}$ to $\mathrm{CH}_{4}$. It is necessary to utilize $\mathrm{H}_{2}$ since gaseous concentrations cannot afford build up, or methanogenic archaeal activity will be inhibited [2,4]. The accumulated $\mathrm{CH}_{4}$ in the gut is excreted through eructation to decrease bloating. Bloating occurs when these metabolized gases are retained within the gastrointestinal tract, causing swelling in the stomach.

The potential answer to preventing more air pollution, and in turn decelerating the effects of climate change, lies in bioremediation. This process utilizes either natural or engineered microorganisms to remove contaminants from the environment [5]. Bioremediation is a new sector of biology that has proven extensive ability to decrease localized pollutants. It has been used to clean up oil spills and gas leaks, but has yet to be determined whether this can be applied to atmospheric pollutants. The association between microbiology, animal science and environmental science needs to be explored. Through bioremediation, a sustainable solution for climate change can be created. 
UNDERGRADUATE RESEARCH IN NATURAL AND CLINICAL SCIENCE AND TECHNOLOGY (URNCST) JOURNAL Read more URNCST Journal articles and submit your own today at: https://www.urncst.com

\section{Research Hypothesis}

This study aims to investigate bioremediation tactics and question if they can be used to decrease levels of methane gas produced by cows, in order to reduce the air pollution driving climate change. It is hypothesized that the production of methane gas from dairy cattle can be reduced through the addition of microbes into their microbiome, ultimately decreasing the carbon footprint of dairy cattle.

\section{Rationale}

As climate change threatens the world, we must find sustainable solutions, for the planet and species health, that allow us to continue life comfortably whilst reducing the harmful gaseous contaminants in the air. This proposal offers a solution to one of the biggest contributors to climate change, greenhouse gases. The average cow can release up to 250 liters of $\mathrm{CH}_{4}$ per day. $\mathrm{CH}_{4}$ has a half-life of 8-12 years [8]. Currently, the atmospheric concentration of $\mathrm{CH}_{4}$ is more than 1800 parts per billion (ppb) [8,9]. While this does not appear to be a lot, $\mathrm{CH}_{4}$ has 80 times more atmospheric toxic potency than $\mathrm{CO}_{2}$ and levels are constantly being augmented [8]. A previous study on $\mathrm{CH}_{4}$ production in cows looked at lowering gaseous levels through animal nutrition. Researchers had two separate trial groups of cattle, one receiving canola oil through nutritional dietary supplementation, and the other group receiving a live yeast, Saccharomyces cerevisiae, implanted in their fodder. The investigators hypothesized that either the addition of a supplement or live yeast would lead to decreased methanogen activity in the breakdown of fodder. The results from this study were ambiguous, but led to the philosophy that modifying cattle microbiomes may prove beneficial in decreasing the $\mathrm{CH}_{4}$ production [3]. The knowledge gap in the literature is a connection between manipulating the cow microbiome, and relevance to $\mathrm{CH}_{4}$ and climate change. There is also little to no research on acetogen-methanogen microbiome relationships and their effects on $\mathrm{CH}_{4}$ production. By implementing the knowledge of acetogen and methanogen competition into physiological practice, a feasible methodology for manipulating cattle microbiomes may be produced. The previous research on the competition between these microbes gives insight to the ability for acetogenic survival in a rumen environment. There is a need for an interdisciplinary approach by combining multiple areas of science such as microbiology, animal science, biochemistry and bioengineering. Hence, we tend to look further towards future applications of bioremediation to decrease $\mathrm{CH}_{4}$ and in turn, reduce greenhouse gas emissions. With cattle being major $\mathrm{CH}_{4}$ producers, the definitive relationship between acetogenmethanogen microbiomes can give insight on the modification of cattle microbiomes and its feasibility in decreasing $\mathrm{CH}_{4}$ production. This research intends to close the knowledge gap by integrating previously established methods on studying climate change mitigation with the novel knowledge and methodology of manipulating cattle microbiomes. Therefore, creating a more modern solution for climate change and augmenting it towards the future of greenhouse gas mitigation.

\section{Methods}

Animals and Groups

This experimental study will utilize three groups. The control group and two dose-response dependant experimental groups (control, Group A $10^{6}$ $\mathrm{CFU} / \mathrm{mL} / \mathrm{OD}_{600 \mathrm{~nm}}$, Group B $\left.10^{9} \mathrm{CFU} / \mathrm{mL} / \mathrm{OD}_{600 \mathrm{~nm}}\right)$. The experimental unit will be Canadian laboratory-bred Holstein dairy calves. Holstein cattle are the most commonly used farming breed of dairy cows in Canada. With large dairy farming practices, the overall $\mathrm{CH}_{4}$ production from this sector is extensive. Young cattle have developing microbiomes that are easy to manipulate, allowing for the survival of implanted $R$. hydrogenotrophicus [1,4]. Each group will consist of 10 cows randomly allocated based on a random sequence generator and each one will be fitted with a rumen cannula, as shown in the Figure 1 illustration.

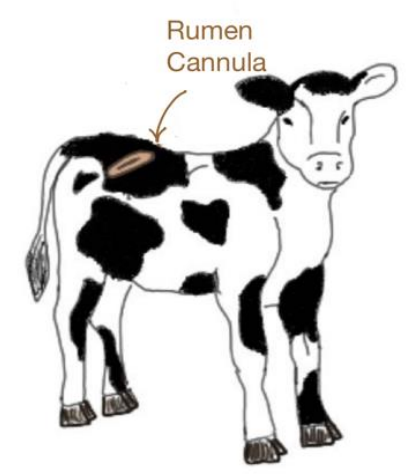

Figure 1: Diagram showing a rumen cannula placed on a young calf. Placement on the diagram indicates where the rumen is located relative to a young calf's anatomy.

Calves aged 14 months will be housed according to their groupings in three enclosed open stall concepts measured $24 \mathrm{~m}^{2}$ in accordance with the number of cows and their weight, as determined by the Canadian Council on Animal Care [10]. They will have free access to an automatic water dispenser, a salt block for additional nutrients/occupation and a hay-corn mixture (HCM) [7]. Each room will have an ambient temperature between $19-20^{\circ} \mathrm{C}$, following a 12-hour light-dark cycle between 6:00-18:00 hours [10]. 


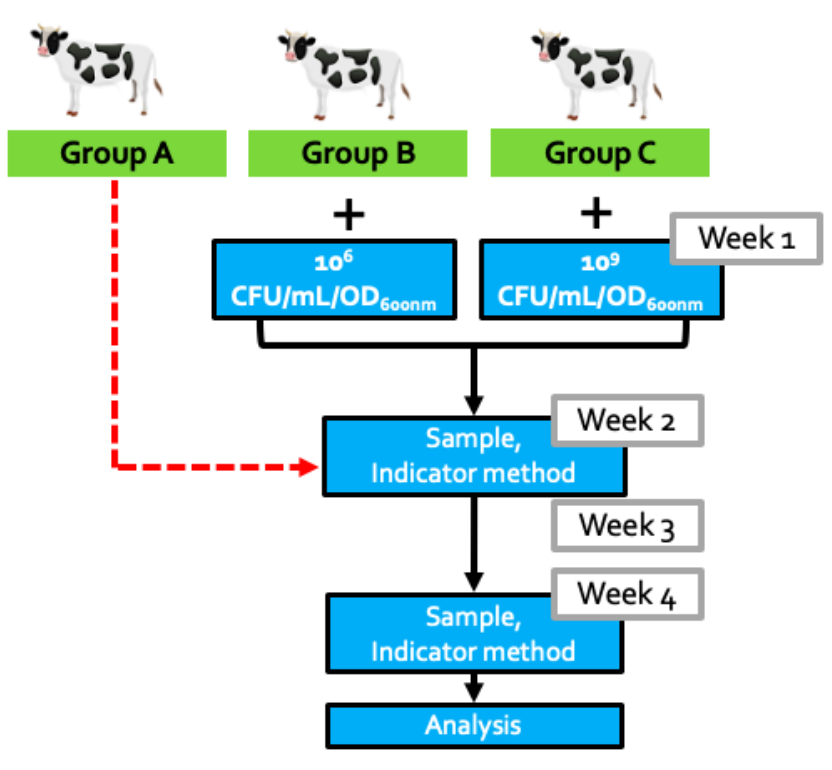

Figure 2: Outline of experimental method. This shows each experimental group and how we flow from addition of microorganisms to sampling times throughout the duration of the study.

\section{Sampling Methods and Timeline}

A rumen cannula will be inserted into the central rumen for sampling. The fitted rumen cannulas act as an access porthole to the cow's rumen. It is placed upon the surface of a cow but allows accessible entryway into their rumen. The acetogen, Ruminococcus hydrogenotrophicus, will be grown in a $\mathrm{H}_{2} / \mathrm{CO}_{2}$ mixtorphy [2,11]. This bacterium, and its respective genus Ruminococci, is largely found in the guts of both humans and ruminants. Thus making it a good candidate for experimentation. During week 1 , respective concentrations of $R$. hydrogenotrophicus for groups $\mathrm{B}$ and $\mathrm{C}$ will be directly inserted into the rumen using a syringe. Group A will feed on the HCM with no culture added [3,7]. Group B will feed on HCM and have $10^{6} \mathrm{CFU} / \mathrm{mL} / \mathrm{OD}_{600 \mathrm{~nm}}$ of $R$. hydrogenotrophicus inserted into the rumen. Group $\mathrm{C}$ will feed on HCM and have $10^{9}$ $\mathrm{CFU} / \mathrm{mL} / \mathrm{OD}_{600 \mathrm{~nm}}$ of $R$. hydrogenotrophicus inserted into the rumen. Concentrations of $10^{6} \mathrm{CFU} / \mathrm{mL}^{\circ} \mathrm{OD}_{600 \mathrm{~nm}}$ and $10^{9} \mathrm{CFU} / \mathrm{mL} / \mathrm{OD}_{600 \mathrm{~nm}}$ are being used for groups $\mathrm{B}$ and $\mathrm{C}$, respectively. This is to examine a dose-dependent relationship between the amount of microbes added and the amount of $\mathrm{CH}_{4}$ produced. Ruminal samples will be taken at weeks 2 and 4 to ensure microbial growth is occurring, as illustrated in the timeline of Figure 2. An open path laser (OPL) will be used to measure $\mathrm{CH}_{4}$ emission from the respective experimental groups (Figure 3). The OPL takes measurements continuously for the 4-week study duration. Nutrient absorption will also be analyzed using the indicator method in weeks 2 and 4, to monitor and ensure adequate health of the cattle. Results from both nutrient absorption and $\mathrm{CH}_{4}$ emission will be compared between control and experimental groups. Methane gas analysis will be performed using OPL measurements.

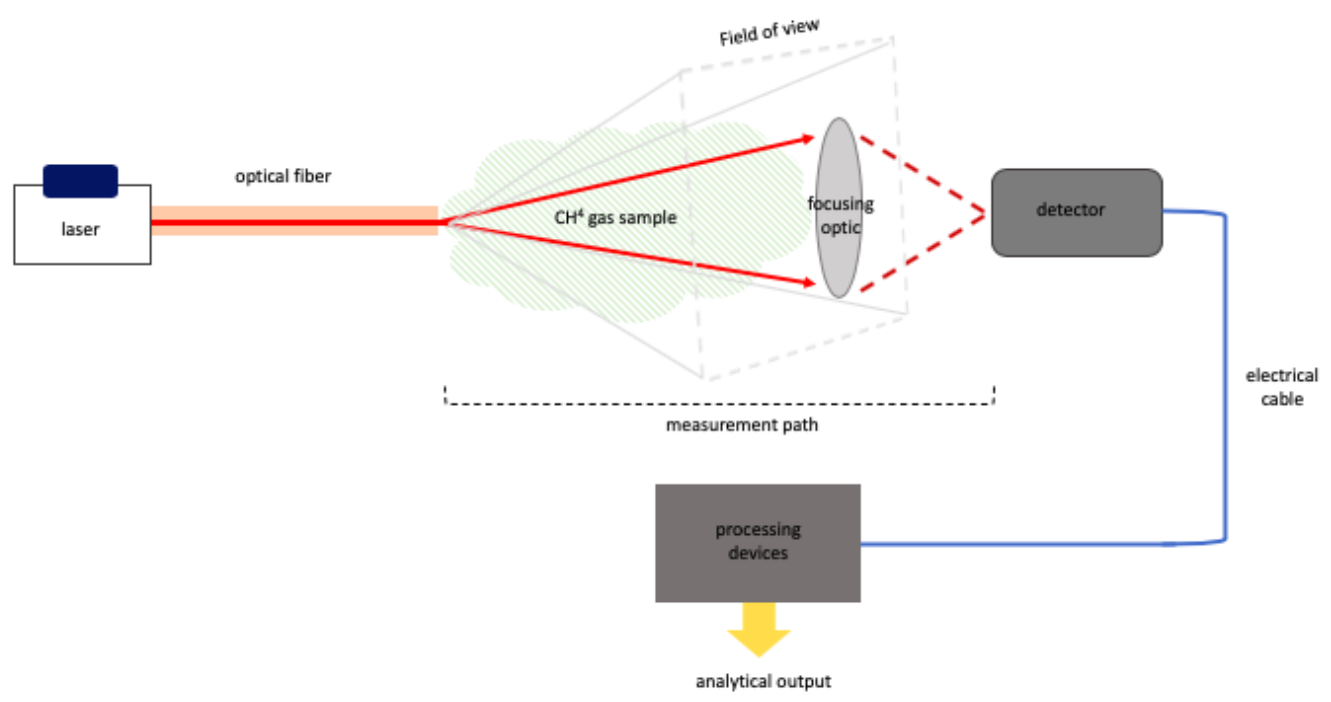

Figure 3: Simplified schematic showing the mechanism of an open path laser (OPL) and how it takes $\mathrm{CH}_{4}$ gas samples.

Experimental Analysis

Microbial analysis of samples from 4 sites within central rumen will also be executed to observe which area the microbes decided to colonize [7]. Samples taken from the cannula will be subjected to serial dilutions to assess the morphology, physiology and species diversity of microorganisms (Figure 4). Statistical examination of results will be compared between groups. Hypothesis 
UNDERGRADUATE RESEARCH IN NATURAL AND CLINICAL SCIENCE AND TECHNOLOGY (URNCST) JOURNAL Read more URNCST Journal articles and submit your own today at: https://www.urncst.com

testing and ANOVAs will be used to compare data between groups (statistical significance determined by $\mathrm{p}<0.05$ ).

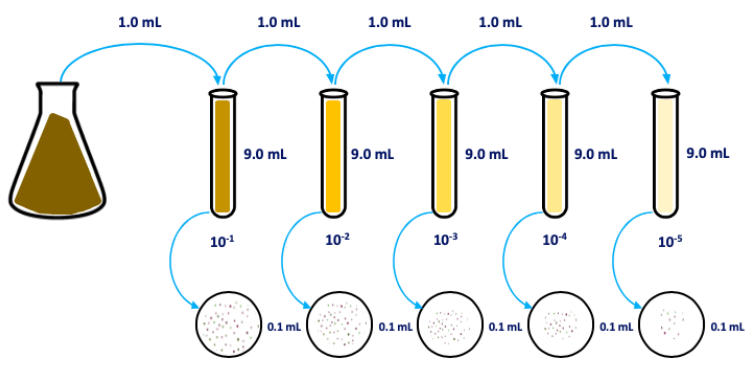

Figure 4: Steps of a serial dilution shown by a decrease in concentration as the sample is further diluted.

\section{Results}

Proposed results will include the quantified release of $\mathrm{CH}_{4}$ from rumen digestion in cattle with different or no concentrations of $R$. hydrogenotrophicus inserted. This research proposal does not include numerical results, as it is strictly an outline for a prospective study to be based off.

\section{Discussion}

This research proposal aims to provide a methodology and experimental design for reducing $\mathrm{CH}_{4}$ emissions from one of the largest emission release sectors, agriculture and specifically cattle farming. The suggested approach aims to alter rumen digestion with the use of bioremediation tactics. The proposed groups will provide results on how modifying a young cow's ruminal microbial population can change the $\mathrm{CH}_{4}$ production released through digestion.

By using young cattle with developing rumens, their microbiomes can easily be altered. The suggested groups will receive different concentrations of $R$. hydrogenotrophicus isolated and obtained from the lab, to outcompete the pre-existing ruminal colonies of methanogenic archaea $[2,4]$. The use of OPL measurements will provide quantitative data on $\mathrm{CH}_{4}$ production in cattle with varying concentrations of inserted $R$. hydrogenotrophicus. In order to ensure the proper growth and maintenance of the proposed inserted acetogen colony, samples taken from the rumen-cannulated cows will be analyzed in terms of growth of the novel colony. Statistical analysis between groups will determine the results of competition between acetogens and methanogens in the microbiome. Results will show change in levels of methane release, dependant on the acetogenic colony concentrations in the rumen. As there is minimal research on $\mathrm{CH}_{4}$ production dependant on acetogen-methanogen microbial relationships, this proposal aims to observe this affiliation.

Investigating this relationship will provide a further understanding of altered rumen microbiomes and how they can be used to reduce the $\mathrm{CH}_{4}$ production. The acetogen $R$. hydrogenotrophicus and its dose-dependent relationship to decreased $\mathrm{CH}_{4}$ production will be determined. This proposed reduction in $\mathrm{CH}_{4}$ release will provide crucial evidence to depreciating the comprehensive carbon footprint of cattle farming practices.

\section{Conclusions}

The implementation of bioremediation tactics on the microbiome of cattle can produce feasible results. The acetogens will compete with methanogens in the rumen to decrease $\mathrm{CH}_{4}$ production and metabolize $\mathrm{H}_{2}$ more efficiently [2]. The decreased methane production can help reduce the overall carbon footprint of cattle, and therefore be applicable to reversal climate change tactics. This proposal is being presented with hopes that future studies exploring climate change mediation will be inspired by this novel approach using bioremediation. The interdisciplinary nature of this proposal combines fields of environmental science, engineering, microbiology and ecology to put together an experiment that has enormous potential in stopping climate change. These climate change tactics can then be augmented on a larger scale.

\section{List of Abbreviations Used}

Colony forming unit (CFU): a counting quantity represented by a single colony formed on solid medium from a single or few cells [12].

Open path laser (OPL): gas detectors that emit a beam of infrared light that is capable of detecting a wide range of gasses. OPL's will be specific to the gas they are aiming to detect [14].

Optical density $\left(\mathrm{OD}_{600 \mathrm{~nm}}\right)$ : an indirect method of counting bacteria measured using a spectrophotometer, typically at a wavelength of $600 \mathrm{~nm}$ [12].

\section{Conflicts of Interest}

The author(s) declare that they have no conflict of interests.

\section{Ethics Approval and/or Participant Consent}

In accordance with the Canadian Council on Animal Care open stall concepts measured $24 \mathrm{~m}^{2}$ in accordance with the number of cows and their weight will be used. Development of policies and standard operating procedures (SOP's) will be developed prior to the conduction of the research. An Animal Care Committee team will be established with knowledge of young calve behaviour and handling. Conforming to the use of animal in research protocols; prevention of unnecessary pain and stress will be at high recognition.

\section{Authors' Contributions}

AS-O, AS: Made contributions to the study design, topic idea, methodology, poster and gave final approval of the version to be published. 
UNDERGRADUATE RESEARCH IN NATURAL AND CLINICAL SCIENCE AND TECHNOLOGY (URNCST) JOURNAL Read more URNCST Journal articles and submit your own today at: https://www.urncst.com

\section{Acknowledgements}

We would like to extend thanks to Dr. Cathy Bauman, Dr. Julie Denstedt, Dr. Kate Shoveller, Cosette Ayoub, and the Guelph USCC executive team for providing their guidance, knowledge and help.

\section{Funding}

This research proposal was not funded.

\section{References}

[1] Kasuya $\mathrm{H}$ and Takahashi J. Methane Emissions from Dry Cows Fed Grass or Legume Silage. Asian-Australasian Journal of Animal Sciences. 2010 Apr 2;23(5):563-566. http://dx.doi.org/10.5713/ajas.2010.90488

[2] Lan W and Yang C. Ruminal methane production: Associated microorganisms and the potential of applying hydrogen-utilizing bacteria for mitigation. Science of The Total Environment. 2019 Mar 1;654:1270-1283. http://dx.doi.org/10.1016/j.scitotenv.2018.11.180

[3] Bayat A, Kairenius P, Stefański T, Leskinen H, Comtet-Marre S, Forano E, Chaucheyras-Durand F and Shingfield K. Effect of camelina oil or live yeasts (Saccharomyces cerevisiae) on ruminal methane production, rumen fermentation, and milk fatty acid composition in lactating cows fed grass silage diets. Journal of Dairy Science. 2015 Feb 25;98(5):31663181. http://dx.doi.org/10.3168/jds.2014-7976

[4] Ungerfeld E. Inhibition of Rumen Methanogenesis and Ruminant Productivity: A Meta-Analysis. Frontiers in Veterinary Science. 2018 Jun 19;5:113. http://dx.doi.org/10.3389/fvets.2018.00113

[5] Dangi A, Sharma B, Hill R, and Shukla P. Bioremediation through microbes: systems biology and metabolic engineering approach. Critical Reviews in Biotechnology. 2018 Sep 9;39(1):79-98. http://dx.doi.org/10.1080/07388551.2018.1500997

[6] Warner D, Podesta S, Hatew B, Klop G, van Laar H, Bannink A and Dijkstra J. Effect of nitrogen fertilization rate and regrowth interval of grass herbage on methane emission of zero-grazing lactating dairy cows. Journal of Dairy Science. 2015 Mar 12;98(5):3383-3393. http://dx.doi.org/10.3168/jds.2014-9068

[7] Bayat A, Tapio I, Vilkki J, Shingfield K and Leskinen H. Plant oil supplements reduce methane emissions and improve milk fatty acid composition in dairy cows fed grass silage-based diets without affecting milk yield. Journal of Dairy Science. 2018;101(2):1136-1151. http://dx.doi.org/10.3168/jds.2017-13545

[8] Borunda A. Methane, explained [Internet]. National Geographic. 2019 [cited 20 November 2019]. Available from: https://www.nationalgeographic.com/environment/ global-warming/methane/\#close

[9] Laboratory O. Current Greenhouse Gas Concentrations [Internet]. Cdiac.ess-dive.lbl.gov. 2019 [cited 20 November 2019]. Available from: https://cdiac.essdive.lbl.gov/pns/current ghg.html

[10] CCAC - Canadian Council on Animal Care: Guidelines [Internet]. Ccac.ca. 2019 [cited 21 November 2019]. Available from: https://www.ccac .ca/en/standards/guidelines/

[11] Bernalier A, Willems A, Leclerc M, Rochet V, Collins M. Ruminococcus hydrogenotrophicus sp. nov., a new $\mathrm{H} 2$ /CO 2 -utilizing acetogenic bacterium isolated from human feces. Archives of Microbiology. 1996;166(3):176-183. https://doi-org.subzero.lib.uoguelph .ca/10.1007/s002030050373

[12] Parker N, Schneegurt M, Tu A, Forster B, Lister P. Microbiology. Houston, Texas: OpenStax; 2016.

[13] Mongeon MS. Ontario Ministry of Agriculture, Food and Rural AffairsMario [Internet]. Ruminations on Rumination. Milk Producer Magazine; 2016 [cited 22 Nov 2019]. Available from: http://www.omafra.gov.on .ca/english/livestock/dairy/facts/ruminations.htmLaserbased

[14] Open Path Gas Detection - A Cost Effective Way to Improve Safety [Internet]. Envirotech Online. [cited 2019Nov22]. Available from: https://www.envirotechonline.com/news/health-and-safety/10/msatechnologies-and-enterprise-services-gmbh-auer/laserbased-open-path-gas-detection-a-cost-effective-way-toimprove-safety/43763

[15] de Ondarza MB. The stomach of the dairy cow [Internet]. Animal Health. [cited 2019 No v22]. Available from: http://www.milkproduction.com/ Library/Scientific-articles/Animal-health/The-stomachof-the-dairy-cow/

[16] Abdel-Fattah M, Sedeek AM, Suliman AIA. An effective device for rumen cannulation. Vet On-Line The International Journal of Veterinary Medicine. 
UNDERGRADUATE RESEARCH IN NATURAL AND CLINICAL SCIENCE AND TECHNOLOGY (URNCST) JOURNAL

Read more URNCST Journal articles and submit your own today at: https://www.urncst.com

\section{Article Information}

Managing Editor: Jeremy Y. Ng

Peer Reviewers: Janice Tai, Jordan Donders

Article Dates: Received May 28 20; Accepted Sep 17 20; Published Oct 1420

\section{Citation}

Please cite this article as follows:

Sekyi-Otu A, Smith A. Bioremediation: How to decrease greenhouse gas emissions through cattle. URNCST Journal. 2020

Oct 14: 4(9). https://urncst.com/index.php/urncst/article/view/192

DOI Link: https://doi.org/10.26685/urncst.192

\section{Copyright}

(C) Atiya Sekyi-Otu, Alexa Smith. (2020). Published first in the Undergraduate Research in Natural and Clinical Science and Technology (URNCST) Journal. This is an open access article distributed under the terms of the Creative Commons Attribution License (https://creativecommons.org/licenses/by/4.0/), which permits unrestricted use, distribution, and reproduction in any medium, provided the original work, first published in the Undergraduate Research in Natural and Clinical Science and Technology (URNCST) Journal, is properly cited. The complete bibliographic information, a link to the original publication on http://www.urncst.com, as well as this copyright and license information must be included.

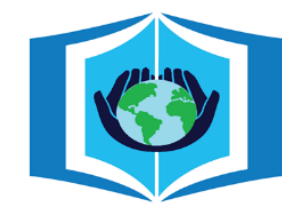

\section{URNCST Journal}

"Research in Earnest"

\section{Funded by the \\ Government \\ of Canada}

\section{Canadà̀}

Do you research in earnest? Submit your next undergraduate research article to the URNCST Journal!

|Open Access | Peer-Reviewed | Rapid Turnaround Time | International |

| Broad and Multidisciplinary | Indexed | Innovative | Social Media Promoted |

Pre-submission inquiries? Send us an email at info@urncst.com | Facebook, Twitter and LinkedIn: @ URNCST

Submit YOUR manuscript today at https://www.urncst.com! 